\section{Sciences}

Volume 16, Issue 4, (2021) 1680-1703

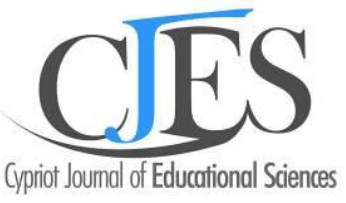

www.cjes.eu

\title{
Formation of professional mobility of future specialists in the process of choreographic education
}

Didar K. Azizkhanova1 ${ }^{*}$, M. Auezov South Kazakhstan University, Tauke Khan av.5, 160001, Shymkent, Kazakhstan, https://orcid.org/0000-0003-1332-7048

Negmatzhan Sh. Almetov², M. Auezov South Kazakhstan University, Tauke Khan av.5, 160001, Shymkent, Kazakhstan https://orcid.org/0000-0001-7374-5677

Sholpan Zh. Turdaliyeva3, M. Auezov South Kazakhstan University, Tauke Khan av.5, 160001, Shymkent, Kazakhstan https://orcid.org/0000-0001-7296-5221

Akmaral B. Aitzhanova4, M. Auezov South Kazakhstan University, Tauke Khan av.5, 160001, Shymkent, Kazakhstan https://orcid.org/0000-0003-0609-6149

Gulmira M. Musakhanova5, M. Auezov South Kazakhstan University, Tauke Khan av.5, 160001, Shymkent, Kazakhstan https://orcid.org/0000-0001-5614-9072

\section{Suggested Citation:}

Azizkhanova, D. K., Almetov, N. S., Turdaliyeva, S. Z., Aitzhanova, A. B., \& Musakhanova, G. M., (2021). Formation of professional mobility of future specialists in the process of choreographic education. Cypriot Journal of Educational Science. 16(4), 1680-1703. https://doi.org/10.18844/cjes.v16i4.6050

Received from April 25, 2021; revised from June 24, 2021; accepted from August 25, 2021.

(C2021 Birlesik Dunya Yenilik Arastirma ve Yayincilik Merkezi. All rights reserved.

\section{Abstract}

One of the main conditions for the success of students of the specialty "choreography" in the modern labor market is professional mobility. This article is therefore aims to address the problem of forming professional mobility in higher educational institutions. The essence and significance of the formation of professional mobility of students of the specialty "choreography" was determined by the methods of analysis of psychological, pedagogical, scientific-methodological and special literature. Through the analysis of educational programs of Bachelor's degree in "choreography" in higher educational institutions, new opportunities and content for the formation of professional mobility of future choreographers are identified. With the help of systematization and evaluation methods, the results of improving the formation of professional mobility of students studying in the educational programs "choreography" were summed up. It was concluded that the formation of professional mobility of future choreographers should be a purposeful and systematic process, covering all stages of students' assimilation of educational programs, and must be guided by the achievement of high indicators of the formation of professional mobility.

Keywords: choreographic education, future choreographer, professional mobility, University, content of choreographic education, formation of professional mobility;

\footnotetext{
* ADDRESS OF CORRESPONDENCE: Didar K. Azizkhanova, M. Auezov South Kazakhstan University, Tauke Khan av.5, 160001, Shymkent, Kazakhstan

Email address: elmira.uaidullakyzy1988@gmail.com
} 


\section{Introduction}

The development of modern society is characterized by a continuous increase in the volume and complexity of information flows, the speed and rapid movement of economic and social processes (Tezer, 2020). These processes lead to changes in the requirements for professional and personal qualities of specialists of various industries, lack of demand for specialists in the labor market, competition and the formation of professional competencies for successful work. Already, authoritative experts and scientists predict that in the near future many professions will disappear, and not only the content of the work of owners of traditional professions and professions will change, but also other aspects of it (Berezhnaya, 2008). In a changing professional field, a specialist should be flexible, agile, mobile, adaptable to innovations and changes, responsive to changes, i.e. professionally mobile.

Professional mobility is becoming one of the most pressing issues for owners of creative professions, including choreographers of one of the traditional professions (Mead, 2020). Today, the art sphere is also not excluded from the new conditions and requirements of changes in society: competition in the field of educational services of art and art, changes in the needs and tastes of people. New ways of processing and presenting works of dance art to the audience in the context of digitalization, instability of demands and requirements in the labor market and other factors increase the relevance of the problem of professional mobility of choreographers.

In addition, the professional activity of a modern choreographer is characterized by greater mobility and greater functionality (Mead, 2020; Lusdoc \& Namoco, 2019). A specialist graduating from a university is obliged to perform a number of different functions in a number of areas, to act successfully in abnormal situations, and therefore to be professionally mobile. A modern choreographer-dancer, teacher, manager, researcher in the field of art, etc.should be professionally and personally ready to work, quickly change their work and field of activity.

The above-mentioned guidelines are particularly relevant in the process of training future choreographers at a university, since today's student - future choreographer should be capable and ready for various types of professional activities: artistic, organizational, managerial, pedagogical, informational and analytical, innovative, diagnostic, methodological, consulting, educational activities in professional and personal aspects (Limanskaya et al., 2020).

In particular, the competence base in the training of future choreographers will become the basis for the formation of their professional mobility (Tezer, 2020). The competence platform opens the way to the development of universal professional knowledge, skills and abilities of the future specialist. However, the analysis of the experience of training future specialists in higher education institutions shows that the priority in the implementation of the competence approach is the development of special professional knowledge, skills and abilities, and the formation of professional mobility of a specialist is not purposefully and systematically carried out (Lusdoc \& Namoco, 2019).

The problem of professional mobility is a complex problem in science. Philosophers and sociologists raised the issue of professional mobility in the 70s of the last century. In recent years, scientists and researchers from various fields have been interested in the problem of professional mobility, especially researchers from the fields of psychology and pedagogy pay special attention to this 
problem (Leijen et al., 2006; Lusdoc, C. S., \& Namoco, 2019).Various definitions of the concept of professional mobility are given in psychological and pedagogical research papers:

- Qualitative characteristics of the personality of the specialist, which provides rapid adaptation to changes in the professional field (E.A. Nikitina, S.L. Novolodskaya);

- Dynamic characteristics of the person that determine the success of adaptation to changing conditions (B.M. Igoshev, G.V. Medenkova);

- an internal mechanism of human development, professional growth and readiness to realize their personal potential, able to realize their needs in a certain type of activity (L.V. Goryunova, Y.I. Kalinovsky, I.V. Nikulina).

However, research on the formation of the foundations of professional mobility of future choreographers is only at the initial stage. Scientific works on the formation of professional mobility of future choreographers are still scarce in higher educational institutions (Mead, 2020). The current system of training future choreographers is designed without taking into account the formation of the quality of professional mobility of a specialist and prioritizes the tasks of forming and developing special competencies. The training of students -future choreographers in higher educational institutions is focused on traditional methods and technologies for the formation of their dance performance and minor pedagogical abilities (Carraro \& Trinder, 2021). In the field of higher professional education, the issues of training choreographers who act flexibly, quickly, and mobile in accordance with the constantly changing needs of society, the labor market and the individual in the field of art and education in the field of art have not been fully resolved. This fact in the changing labor market significantly complicates the successful integration of the future specialist into the professional environment, in particular, his professional activities in choreographic, theatrical, pedagogical or musical groups, management of art organizations (Ilhan, 2018). At the same time, the priority of training future choreographers is to focus on a narrow range of professional competencies, limiting the range of creative capabilities of the choreographer and preventing him from fully realizing his potential in professional activities.

\subsection{Literature review:}

From the outside, it seems that professional mobility should be a characteristic of high-tech production workers, areas of human activity that undergo the greatest changes in the content and nature of the work of specialists. However, numerous studies and our observations in recent years show that today professional mobility is also one of the main professional characteristics of people of creative professions, such as choreographers (Georgiadou, Florou \& Georgiadou, 2021). Choreographers who work mainly in the field of art always show creativity. Choreographers are inherently creative professionals. Among the professionally significant qualities and professional competencies of a choreographer, a significant share is occupied by qualification characteristics related to creative activity.

As Berezhnaya (2008) correctly noted, "in psychological and pedagogical research, there was a tendency to understand creativity as one of the characteristics of professionalism, thereby pushing the professional beyond the scope of any profession. Creativity is understood as an immanent characteristic of a high level of any profession" (Berezhnaya, 2008) 
The authors believe that with the improvement and deepening of the main subject, specific danceperforming competencies, at the same time, it is necessary to think about expanding the psychological component in the implementation of a competency approach to the formation of professionally significant personal qualities of the future choreographer. It should also be taken into account that the development of the creative abilities of the future choreographer will not fully ensure his readiness for professional mobility (Mishchenko et al., 2016)

In the training of the future choreographer, the stereotypes of educational and professional activity of the future are formed(Ilhan, 2018). It is at this time that the foundation of professional mobility of the future specialist is laid. The main directions of formation of the foundations of professional mobility of the future choreographer in the pedagogical process of the university can be noted as:

- active search and identification of opportunities for professional and personal development of future choreographers of the educational process and the content of higher choreographic education;

- formation of a system of value orientations of future choreographers;

- formation of the image of the future profession.

At the stage of formation of the future choreographer, the student-choreographer should be able to internally feel the multiplicity of development opportunities, compare personal value orientations with universal values, perceive the world a s a reality in everyday life, pay attention to the formation of flexibility to adapt to conditions of rapid change.

We believe that the following comments of Berezhnaya (2008) are particularly relevant in terms of the formation of professional mobility of future choreographers: "the future choreographer should be prepared not only professionally, but also psychologically and pedagogically to work with people. Focus should be placed on the development of creativity as the basis for the formation of the individual, and the trainers must understand the mechanisms for the development of creative abilities in special types of artistic activities. The choreographer works with a collective of a certain age. His activity should be focused only on the development of special choreographic abilities, the ability to convey dance drama, video, motion picture, etc., the development of personal creative potential of people in a well-known choreographic community" (Berezhnaya, 2008).

Analysis of literature on the issues of training future choreographers today and the formation of professional mobility in the process of choreographic education of students is considered within the framework of the following approaches:

- socio-economic, i.e. readiness and ability of future choreographers to change the conditions of the labor market;

- mastering new techniques and new technologies within the professional sphere of professional art, as well as, if necessary, related professions (musical performance, art manager, choreographerteacher) or new professions, as well as changing prestige in the space of the professional hierarchy (i.e., promotion at the professional level);

- pedagogical innovation-development of innovations in art and choreographic education, mastering and applying innovations in practice.

The problem of forming the professional mobility of the future choreographer was considered by scientists from different points of view (Mead, 2020). The problem of forming professional skills of choreographers in the conditions of the educational and creative process in higher educational institutions and institutions of culture and art of Kazakhstan has been studied. The author believes 
that" the training of choreographers in higher educational institutions of Kazakhstan is aimed at the effectiveness of the formation of future specialists and the formation of choreographers in the conditions of proper organization of interaction between the activities of local cultural and artistic institutions " (Autili et al., 2019)

From the point of view of the formation of the foundations of professional mobility of future choreographers, it is of interest to be based on the statement of Zharkov (2007) "on a value-oriented, active-action platform as a whole technological process of consistent and systematic implementation in the course of practice of the simulated nature of collective actions of subjects and objects of higher educational institutions and cultural and artistic institutions (von der Lippe, 2010). Pan Zhonghua's article examines the problem of forming dance imagination in the training of choreographersteachers. According to the author, "the choreographic educational process is distinguished from the pedagogical system, the basis, first of all, by the artistic direction in the development of creative abilities of students, including dance imagination. The dance expresses the State, feelings, moods, feelings of the performer and performs the corresponding content" (Pavlenko, 2017)

Most studies have identified the most important tasks for improving the effectiveness of joint pedagogical activities of teachers-choreographers and ballet concertmasters. According to the author, "in the process of work of teachers of special choreographic disciplines and concertmasters as full fledged participants in the pedagogical process, the tasks are to reveal the personality of students, develop their abilities, especially musicality, dance skills, and the ability to see their future profession aesthetically" (Khalid, 2019).

It is also expressed in the work of Yusov (2002). The author considered the problem of poly-artistic development of students. That is, students learn not only one art, but also several types of art. This has unique advantages over mastering a particular type of art. The author rightly believes that Polyartistic education requires the interaction and integration of art forms (Zeer, 2014).

In recent years, research works devoted to the issues of training future choreographers have reflected some aspects of the problem of forming professional mobility (Mead, 2020; Lusdoc \& Namoco, 2019). The experience of choreographic education and the actualization of a competencybased approach in choreographic pedagogy gave a powerful impetus to the orientation of the theory and practice of training future choreographers to the issues of professional mobility.

In general, the theoretical analysis of works devoted to the problems of choreographic education in universities proves that they reflect the following aspects, which serve as the basis for studying the process of forming professional mobility of future choreographers:

- the relative independence of choreographic education, its versatility, integration with various branches of art, and therefore the possibility of going beyond the scope of training of a future choreographer-specialist;

-the main types of activities of future choreographers-specialists in the process of professional training at universities and its content are aimed at preparing students for actions in the context of innovations and changes in the professional and social environment, the formation of internal mechanisms of professional and personal development, the formation of readiness to change themselves and the surrounding professional environment; 
-the content and process of choreographic education contribute to the formation of the future choreographer's ability to change his profession within one profession (choreographer, tutor, teacherchoreographer, manager of a creative team, etc.);

- development of the future choreographer within the specialty (positions of employees of choreographic art - chief choreographer, choreographer stage director, ballet tutor, assistant choreographer, ballet dancer; ballet, song and dance ensemble, dance group dancer; choreographic collective (studio), choreographer of song and dance ensemble);'

- Universities should allow future choreographers to change their profession to a profession that is close in the future in terms of the content of education, to a certain extent, does not require the acquisition of fundamentally new knowledge and skills (for example, choreographer concertmaster, readiness to move to professions in other areas of art).

- education of future choreographers readiness to radically change their profession in today's rapidly changing world (formation of universal competencies, cultural approach to training future choreographers).

However, the pedagogical potential of the content of educational standards and programs in the formation of the foundations of professional mobility of the future choreographer is only the beginning of the formation of this important professional and personal quality of student choreographers, and the formation of professional mobility requires the organization of purposeful activities of teachers and students (Gromova \& Saitova, 2016).

\section{Materials and methods}

In the course of the study, the methodological, theoretical and conceptual foundations of training future choreographers in higher educational institutions; theories and concepts of modern professional mobility; modern methodological bases for the formation of the foundations of professional mobility of future choreographers (systematic, personality-oriented, axiological, acmeological approaches) were taken as the basis. General scientific methods-analysis, generalization; methods of scientific and pedagogical research-analysis of pedagogical experience of training future teachers in higher educational institutions, pedagogical observation, questionnaires, interviews, Testing, written works, pedagogical modeling, experimental and control work, verification of the expediency and effectiveness of the methodological system through the work of a pedagogical experiment were used. Sorting the results obtained, methods of quantitative and qualitative analysis of research results, special methods (Spearman's method of rank correlation, calculation of the unit value index (UVI) (IAn adapted variant of I.A. butova's methodology) were used.

\section{Results}

The experimental work was carried out in order to determine the effectiveness of the pedagogical conditions identified in the course of the study and the methodology developed on its basis for the formation of the foundations of professional mobility of future choreographers was carried out by students of the specialty "choreography" of the Faculty of pedagogy and culture of the M. Auezov South Kazakhstan University. The duration of the internship was four years and covered the entire period of the future choreographer's studies at the University.

Since the academic groups of the specialty" choreography " were small, we did not have the opportunity to divide these groups into experimental and control groups. Experimental groups 
alternated with control groups, i.e. one year the experimental group was replenished, and the second year the control group was replenished. In the experimental group, the bases and methods developed in the course of research for the formation of the foundations of professional mobility of choreographers-students were used. In the control group, the exercises were conducted according to traditional methods.

In the development of a methodology for diagnosing the formation of professional mobility of choreographers-students, we consider (Butova, 2012). In the research work, we adapted the methodology proposed by Butova (2012) to study the dynamics of the formation of the basics of professional mobility of future choreographers.

Considering the professional mobility of future choreographers as the result of our research process, the structural components of the formation of the foundations of professional mobility of student choreographers in the process of choreographic education at the University were identified: motivational, substantive (cognitive), emotional-value, social-communicative. Through these components, their criteria and levels of formation, conclusions were made about the effectiveness of the pedagogical measures (conditions of effectiveness and methodology) developed in the course of the study on the formation of professional mobility of choreographers-students (Table 1).

Table 1. structural model for the formation of professional mobility of future choreographers

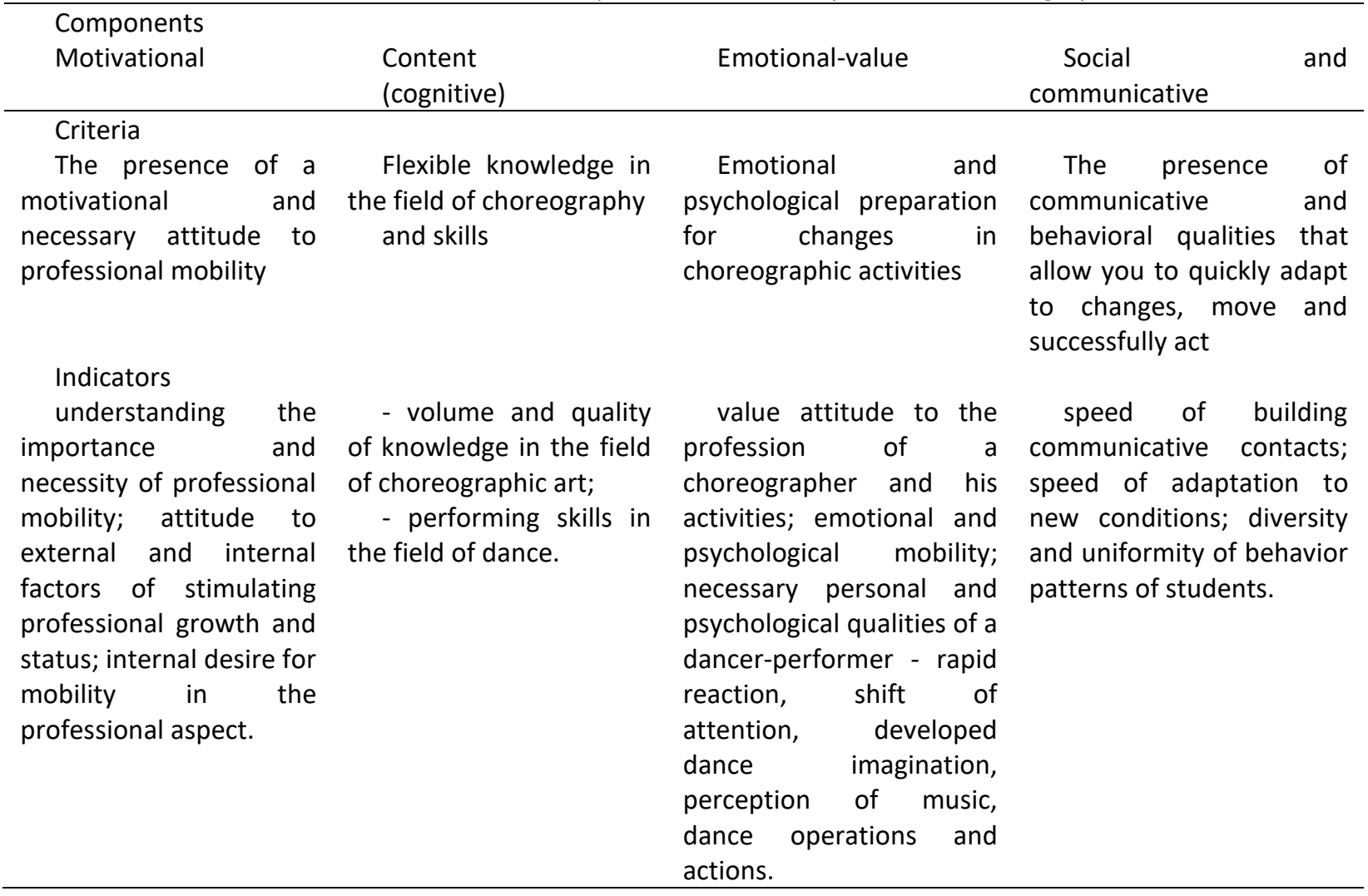

In the research work, we identified three possible levels of formation of professional mobility: reproductive, adaptive (adaptive) and creative. 
Creative level-the student fully understands the importance and necessity of professional mobility. Shows a conscious attitude to external and internal factors of stimulating professional growth and status. There is always an internal desire for mobility in the professional aspect. The volume and quality of knowledge in the field of choreographic art is high. Performing skills in the field of dance are excellent. The value attitude to the profession of a choreographer and his activities is systematic and stable. Shows emotional and psychological mobility in various situations. The dancerperformer has the necessary personal and psychological qualities (rapid reaction, shift of attention, developed dance imagination, perception of music, dance operations and actions) to a high degree. The student quickly builds communicative contacts. Adapts quickly to new conditions. The diversity and uniformity of the student's behavior patterns are clearly observed in different situations.

Adaptive level - the student has a general understanding of the importance and necessity of professional mobility. Shows an active attitude to external and internal factors of stimulating professional growth and status in the presence of absenteeism (influence of teachers). The internal desire for mobility in the professional aspect is observed only when special conditions are created. The volume and quality of knowledge in the field of choreographic art is average. Performing skills in the field of dance are good. The value attitude to the profession of a choreographer and his activities is often observed, but not stable. Shows emotional and psychological mobility in special situations. The dancer-performer has sufficiently mastered the necessary personal and psychological qualities (rapid reaction, shift of attention, developed dance imagination, perception of music, dance operations and actions). The student's speed of building communicative contacts is average. The rate of adaptation to new conditions is average. The diversity and uniformity of behavior patterns of students is observed only in exceptional cases.

Reproductive level - the student superficially understands the importance and necessity of professional mobility. Shows an indifferent attitude to external and internal factors of stimulating professional growth and status. The internal desire for mobility in the professional aspect is weakly expressed. The volume and quality of knowledge in the field of choreographic art is low. Performing skills in the field of dance are satisfactory. The value attitude of the choreographer to the profession and his activities is not clearly expressed. Does not show emotional and psychological mobility, has little knowledge of the necessary personal and psychological qualities of the dancer-performer (rapid reaction, shift of attention, developed dance imagination, perception of music, dance operations and actions). The student's speed of building communicative contacts is low. The speed of adaptation to new conditions is low. The diversity and uniformity of students ' behavior patterns is not clearly observed.

The motivational component of the formation of the foundations of professional mobility of student choreographers was determined by the following indicators: understanding the importance and necessity of professional mobility; attitude to external and internal factors of stimulating professional growth and status; internal desire for mobility in the professional aspect.

To determine motivation for choreographic activity, we distinguish the following indicators:

1. show interest in choreographic activities.

2. manifestation of activity in educational and choreographic activities.

3. understand the importance of professional mobility.

4. readiness to master new choreographic knowledge.

5. readiness to master new types of choreographic activities.

6. preparation for collective creative and choreographic works.

7. preparation for self-education and self-education. 
8. willingness to change behavior and actions in accordance with changes in the professional sphere.

9. readiness to change professional and personal qualities in accordance with the new requirements.

10. readiness to interact and cooperate with partners in the professional field.

A questionnaire was created for student choreographers on a 10-point scale. For students of choreographic specialties, we set a reference rating for each indicator in the range of 8-10 points. Based on the comparison of reference and real prices, their difference was calculated. For each student, the correlation coefficient of reference and actual values and their average value were calculated:

The calculation of the spearmen rank correlation (ratio) indicator shows a high correlation relationship between the reference and rank (rank) indicators (Table 2).

Table 2. calculation of spearmen's degree correlation coefficient for one choreographer-student

\begin{tabular}{|c|c|c|c|c|c|c|c|c|c|c|}
\hline Degree values & 1 & 2 & 3 & 4 & 5 & 6 & 7 & 8 & 9 & 10 \\
\hline $\begin{array}{l}\text { Reference } \\
\text { sample) price }\end{array}$ & 10 & 10 & 10 & 9 & 9 & 9 & 8 & 8 & 8 & 8 \\
\hline Actual price & 7 & 8 & 8 & 6 & 8 & 8 & 9 & 8 & 6 & 9 \\
\hline Difference (d) & -3 & -2 & -2 & -3 & -1 & -1 & +1 & 0 & -2 & +1 \\
\hline $\mathrm{d} 2$ & 9 & 4 & 4 & 9 & 1 & 1 & 1 & 0 & 4 & 2 \\
\hline Sum (d2) & & & 35 & & & & & & & \\
\hline
\end{tabular}

Rs $=0,76$

The resulting value is in the range of $r s=0.5-0.7$, which characterizes the high correlation relationship between reference and actual rank values according to the Cheddock scale.

The ratio of students who showed different levels of formation of the motivational component of professional mobility at the beginning of the experiment is shown in Table 3.

Table 3. levels of control at the beginning of the experiment and the formation of the motivational component of professional mobility of students of the experimental group

\begin{tabular}{l|l|l|c}
\hline Levels, groups & Reproductive & Adaptive & \\
\hline Stages & & & \\
\hline Control group & $68,0 \%(17)$ & $20,0 \%(5)$ & $12,0 \%(3)$ \\
Experimental group & $60,0 \%(15)$ & $28 \%(7)$ & $12 \%(3)$ \\
\end{tabular}

The content (cognitive) component of the formation of the foundations of professional mobility was measured using the following indicators: the volume and quality of knowledge in the field of choreographic art; performing skills in the field of dance. Here, using the testing method, we determined the volume and quality of students ' knowledge in the field of choreographic art. The test tasks include questions about the theoretical foundations and features of choreographic art, patterns of the creative process, about the history of world and domestic choreographic art, directions and 
trends of its development, specifics and features of the artistic and figurative language of dance, as well as the application of knowledge in the field of choreographic education, taking into account the age characteristics, individual differences, social and psychological characteristics of students.

The data obtained based on the results of the determining experiment (Table 4) indicate that at the beginning of the experiment, the volume and quality of knowledge of students of the control and experimental groups is not sufficiently high.

Table 4. indicators of the content (cognitive) components of the formation of the basis of professional mobility at the beginning of the experiment

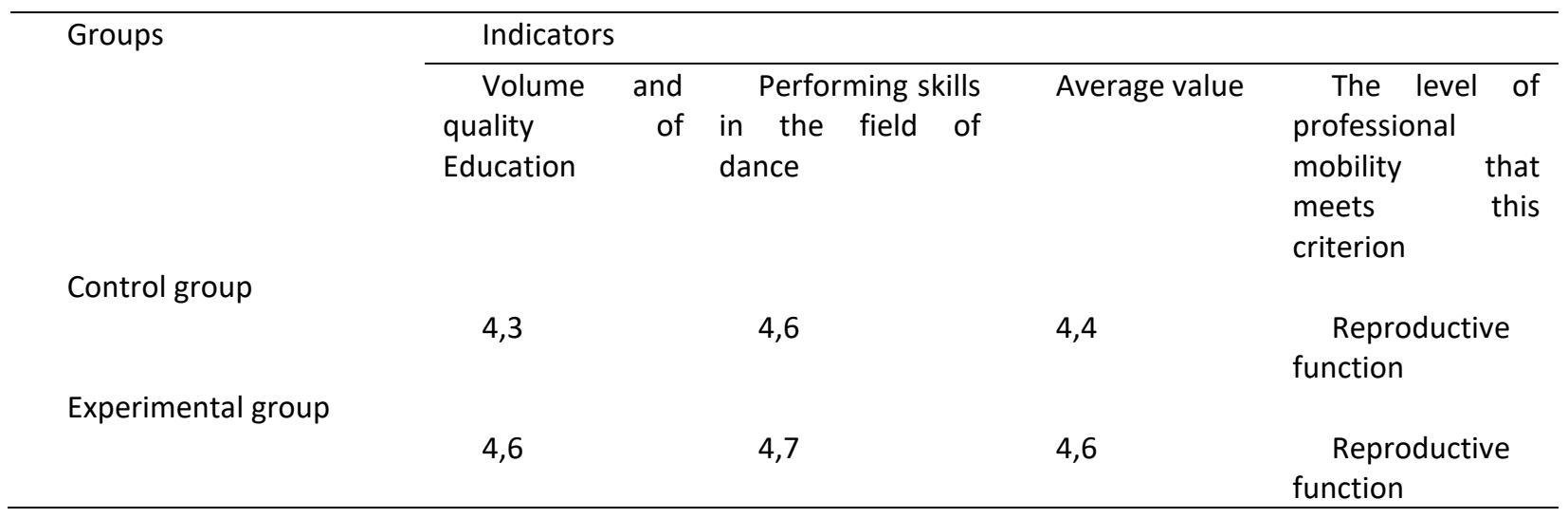

Calculation of the relative frequency of assessment manifestations based on the results of determining the initial levels of formation of the basics of professional mobility the formation of the cognitive component of professional mobility at the beginning of the experiment allows us to determine the ratio of students of different levels (Table 5).

The results of the detection experiment show that the proportion of students with a low level of formation of professional mobility in the content (cognitive) component of professional mobility in the control and experimental groups makes up the majority of them.

Table 5. levels of formation of the basics of professional mobility of students by the content (cognitive) component at the beginning of the experiment

\begin{tabular}{l|c|c|c}
\hline Levels, groups & Reproductive & Adaptive & \\
& & & \\
\hline Control group & & \\
Experimental group & $53,9 \%(14)$ & & $11,5(3)$ \\
\hline
\end{tabular}


At the same time, when sketching the average indicators for the control and experimental groups, an equal value is observed, which indicates approximately the same initial level of quality of the studied students of both groups.

The emotional and value component of the formation of the basics of professional mobility of students was determined by the following indicators: value attitude to the profession of a choreographer and his activities; emotional and psychological mobility; necessary personal and psychological qualities of a dancer-performer-rapid reaction, shift of attention, developed dance imagination, perception of music, dance operations and actions.

The formation of a value relationship to choreographic activity was determined using the valueoriented unit index and using Spearman's degree correlation method. To determine the unity value index (UVI), we have compiled a questionnaire that shows 20 professionally significant qualities of a choreographer. Students were offered to choose 5 qualities that, in their opinion, are most valuable for successful choreographic activities. The calculation of the unit value index (UVI) was carried out on the basis of counting the number of matches of the choice. The more matches there are in the student group, the higher the UVI index.

The generalized data show low results of students ' value ratio both in the control groups of choreographic activity of students and in the experimental groups, with an average of $\mathrm{UVI}=0.22$, which corresponds to the reproductive level of the formation of professional mobility.

The survey data show that the value attitude of students - future choreographers-to choreographic activities is unstable and unconscious (Table 6).

Table 6. Calculation of the unit value index (UVI) index in control and experimental groups (adapted by I. A. Butova's methodology)

\begin{tabular}{|c|c|c|c|c|c|c|c|}
\hline \multicolumn{3}{|c|}{ Control group } & \multicolumn{4}{|c|}{ Experimental group } & \multirow[b]{2}{*}{$\begin{array}{l}\quad \mathrm{Nu} \\
\text { mber } \\
\text { of } \\
\text { electio } \\
\text { ns }\end{array}$} \\
\hline $\begin{array}{l}5 \text { qualities } \\
\text { that received } \\
\text { the maximum } \\
\text { preference }\end{array}$ & $\begin{array}{l}\mathrm{Nu} \\
\text { mber } \\
\text { of } \\
\text { electi } \\
\text { ons }\end{array}$ & $\begin{array}{l}5 \text { qualities } \\
\text { that received } \\
\text { the minimum } \\
\text { Preference }\end{array}$ & $\begin{array}{l}\quad \mathrm{Nu} \\
\text { mber } \\
\text { of } \\
\text { electio } \\
\text { ns }\end{array}$ & $\begin{array}{l}5 \text { qualities } \\
\text { that received } \\
\text { the maximum } \\
\text { preference }\end{array}$ & $\begin{array}{l}\quad \mathrm{Nu} \\
\text { mber } \\
\text { of } \\
\text { electio } \\
\text { ns }\end{array}$ & $\begin{array}{l}5 \text { qualities that } \\
\text { received } \\
\text { minimum } \\
\text { preference }\end{array}$ & \\
\hline $\begin{array}{l}\text { 1) } \\
\text { Performing } \\
\text { dance moves } \\
\text { and exercises }\end{array}$ & 10 & $\begin{array}{l}\text { 1) Correct } \\
\text { muscle } \\
\text { sensations }\end{array}$ & 2 & $\begin{array}{c}\text { 1) Musical } \\
\text { speech }\end{array}$ & 2 & $\begin{array}{l}\text { 1) depth and } \\
\text { breadth of } \\
\text { associative activity }\end{array}$ & 0 \\
\hline 2) Special & & 2) Display of & & 2) Interest & & Willingness & \\
\hline $\begin{array}{l}\text { choreograph } \\
\text { ic knowledge }\end{array}$ & 9 & $\begin{array}{l}\text { speed and } \\
\text { reaction }\end{array}$ & 1 & $\begin{array}{l}\text { to the } \\
\text { choreographic } \\
\text { art }\end{array}$ & 7 & $\begin{array}{l}\text { and ability to } \\
\text { constantly learn }\end{array}$ & 2 \\
\hline $\begin{array}{l}\text { 3) Interest } \\
\text { to dance art } \\
\text { potential }\end{array}$ & 7 & $\begin{array}{l}\text { 3) } \\
\text { desire the } \\
\text { creatively } \\
\text { realize yourself }\end{array}$ & 2 & $\begin{array}{l}\text { 3) Controlling } \\
\text { your own body } \\
\text { movements }\end{array}$ & 7 & 3) Sociability & 2 \\
\hline $\begin{array}{l}\text { 4) Search for } \\
\text { alternative } \\
\text { solutions to } \\
\text { professionally }\end{array}$ & 5 & $\begin{array}{lr}\text { 4) Striving } \\
\text { for } \\
\text { development }\end{array}$ & 2 & $\begin{array}{l}\text { 4) Developed } \\
\text { memory }\end{array}$ & 9 & $\begin{array}{l}\text { 4) Ability to } \\
\text { emotional and } \\
\text { intellectual } \\
\text { synthesis of dance }\end{array}$ & 3 \\
\hline
\end{tabular}




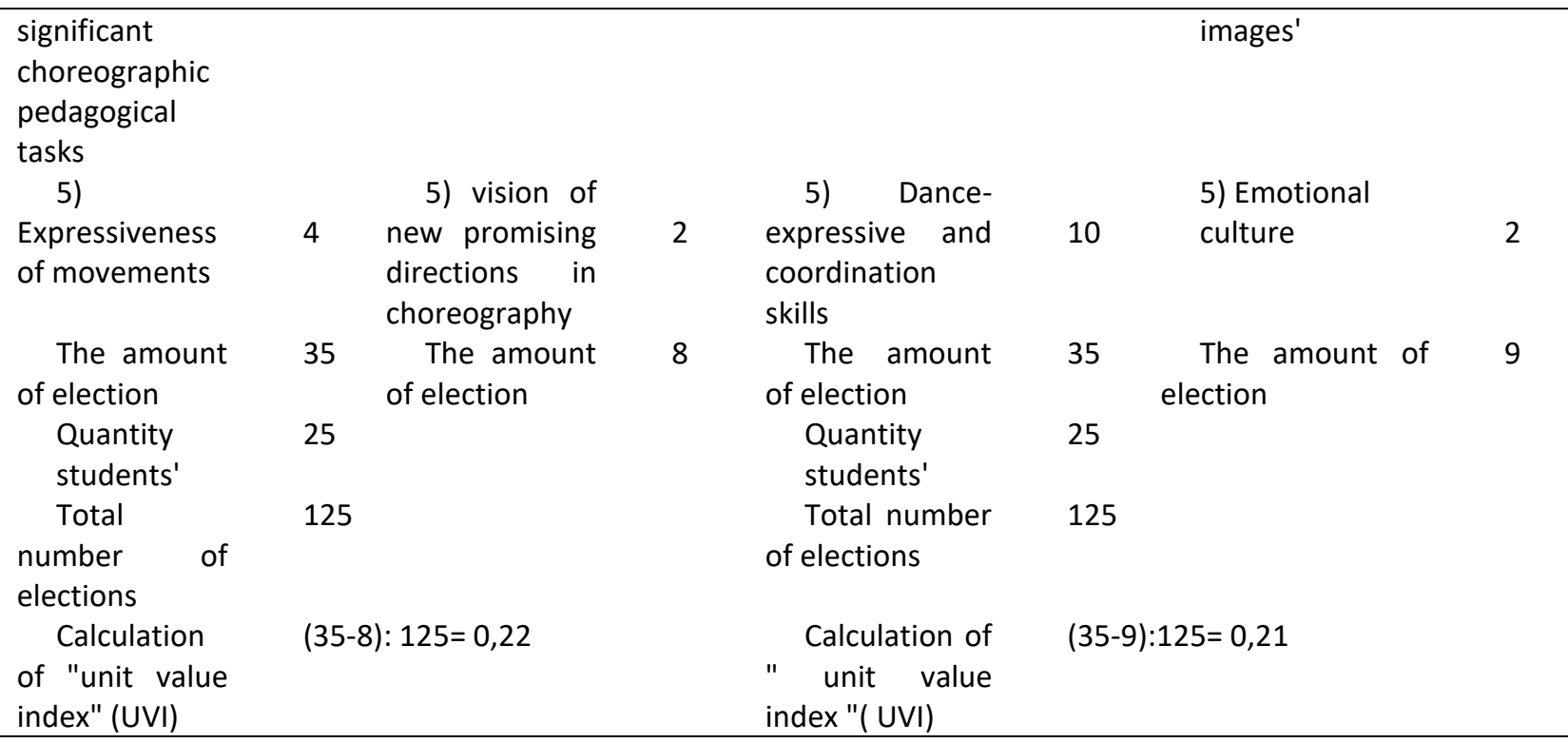

The formation of a value attitude to choreographic activity at the beginning of the experiment indicates a low level of value orientations of students of each of the two groups (Table 7).

Table 7. Formation of a value attitude to choreographic activity (at the beginning of the experiment)

\begin{tabular}{llll}
\hline \multicolumn{2}{c}{ Levels } & \\
\hline & Reproductive & Adaptive & Creative \\
Control group & $14(56 \%)$ & $6(24 \%)$ & $5(20 \%)$ \\
Experimental group & $13(52 \%)$ & $8(32 \%)$ & $4(16 \%)$
\end{tabular}

The socio-communicative component of the formation of the foundations of professional mobility of choreographers-students was determined by the following indicators: the speed of building communicative contacts; the speed of adaptation to new conditions; the diversity and uniformity of behavior patterns of students.

Diagnostics of the level of formation of the foundations of professional mobility of students by the socio-communicative component was carried out in the educational process, collective creative training, performances of students at various concert events.Psychological and pedagogical methods such as interviews, interviews, pedagogical control, the method of self-assessment, and the method of expert assessment were used. The results of diagnostics of the level of formation of the foundations of professional mobility of student choreographers in the socio-communicative component are presented in Table 8. 
Azizkhanova, D. K., Almetov, N. S., Turdaliyeva, S. Z., Aitzhanova, A. B., \& Musakhanova, G. M., (2021). Formation of professional mobility of future specialists in the process of choreographic education. Cypriot Journal of Educational Science. 16(4), 1680-1703. https://doi.org/10.18844/cjes.v16i4.6050

Table 8. Data on diagnostics of the level of formation of the foundations of professional mobility of student choreographers by the social and communicative component

\begin{tabular}{|c|c|c|c|c|c|}
\hline Indicators & \multicolumn{3}{|c|}{ Indicators } & \multirow[b]{2}{*}{$\begin{array}{l}\text { Averag } \\
\text { value }\end{array}$} & \multirow{2}{*}{$\begin{array}{l}\text { Level } \\
\text { Professional } \\
\text { mobilities }\end{array}$} \\
\hline Groups & $\begin{array}{l}\quad \text { speed of } \\
\text { establishing } \\
\text { communication } \\
\text { links }\end{array}$ & $\begin{array}{l}\text { speed of } \\
\text { adaptation } \\
\text { to new } \\
\text { conditions }\end{array}$ & \begin{tabular}{l}
\multicolumn{2}{c}{ diversity } \\
and adequacy \\
of student \\
behavior \\
patterns
\end{tabular} & & \\
\hline Control & 4,7 & 4,9 & 4,7 & 4,7 & $P$ \\
\hline Experimental & 4,8 & 4,7 & 4,8 & 4,7 & $\mathrm{P}$ \\
\hline
\end{tabular}

Table 9 shows the ratio of students who showed different indicators of professional mobility in the socio-communicative component at the beginning of the experiment.

Table 9. Ratio of students with different indicators of professional mobility by social and communicative component

\begin{tabular}{lccc}
\hline Groups & \multicolumn{3}{c}{ Levels } \\
\cline { 2 - 4 } & Reproductive & Adaptive & Creative \\
\hline Control & $14(56 \%)$ & $8(32 \%)$ & $3(12 \%)$ \\
Experimental & $13(52 \%)$ & $9(36 \%)$ & $3(12 \%)$ \\
\hline
\end{tabular}

Thus, the diagnostic results show a predominant reproductive level of professional mobility in choreographers at the initial stage of the pedagogical experiment.

At the stage of the forming experiment in experimental groups, the method of forming the foundations of professional mobility of students-future choreographers, which is based on the pedagogical conditions identified by us. In the control groups, classes were conducted according to the traditional method.

The results obtained by the results of the experiment show a significant difference between the respondents ' indicators for all the criteria of the components of professional mobility of the future choreographer identified by us. Thus, comparative data on the level of formation of the foundations of professional mobility among students in terms of the motivational component (table 10) shows a significant increase in indicators and their average score for all criteria.

Table 10. Comparative distribution of students in control and experimental groups by levels of motivational component of professional mobility at the beginning and end of the experiment

\begin{tabular}{|c|c|c|c|c|c|c|}
\hline \multirow[b]{2}{*}{ Levels, groups } & \multicolumn{2}{|c|}{ Reproductive } & \multicolumn{2}{|l|}{ Adaptive } & \multicolumn{2}{|l|}{ Creative } \\
\hline & $\begin{array}{l}\text { Control } \\
\text { groups }\end{array}$ & $\begin{array}{l}\text { Experimental } \\
\text { groups }\end{array}$ & $\begin{array}{l}\text { Control } \\
\text { groups }\end{array}$ & $\begin{array}{l}\text { Experimental } \\
\text { groups }\end{array}$ & $\begin{array}{l}\text { Control } \\
\text { groups }\end{array}$ & $\begin{array}{l}\text { Experimental } \\
\text { groups }\end{array}$ \\
\hline Stages & & & & & & \\
\hline $\begin{array}{ll}\text { At } & \text { the } \\
\text { beginning of the } \\
\text { experiment }\end{array}$ & $68,0 \%(17)$ & $60 \%(15)$ & $20,0 \%(5)$ & $28 \%(7)$ & $12 \%(3)$ & $12 \%(3)$ \\
\hline $\begin{array}{l}\text { At the end of } \\
\text { the experiment }\end{array}$ & $66,4 \%(16)$ & $8 \%(2)$ & $24 \%(6)$ & $20 \%(5)$ & $12 \%(3)$ & $72 \%(18)$ \\
\hline
\end{tabular}

Diagnostics of the formation of levels based on the indicators of the content component of professional mobility was carried out using the testing method. The results of the comparative data analysis are presented in table 11 . 
Table 11. Comparative distribution of students by levels of formation of the content component of professional mobility at the beginning and end of the experiment

\begin{tabular}{|c|c|c|c|c|c|c|}
\hline \multirow{2}{*}{ Levels, groups } & \multicolumn{2}{|c|}{ Reproductive } & \multicolumn{2}{|l|}{ Adaptive } & \multicolumn{2}{|l|}{ Creative } \\
\hline & $\begin{array}{l}\text { Control } \\
\text { groups }\end{array}$ & $\begin{array}{l}\text { Experimenta } \\
\text { I groups }\end{array}$ & $\begin{array}{l}\text { Control } \\
\text { groups }\end{array}$ & $\begin{array}{l}\text { Experimental } \\
\text { groups }\end{array}$ & Control groups & $\begin{array}{l}\text { Experiment } \\
\text { al groups }\end{array}$ \\
\hline $\begin{array}{l}\text { At the beginning } \\
\text { of the experiment }\end{array}$ & $53,9 \%(14)$ & $50,0(13)$ & $34,6(9)$ & $38,5(10)$ & $11,5(3)$ & $11,5(3)$ \\
\hline $\begin{array}{l}\text { At the end of } \\
\text { the experiment }\end{array}$ & $48 \%(12)$ & $12 \%(3)$ & $44 \%(11)$ & $44 \%(11)$ & $8 \%(2)$ & $44 \%(11)$ \\
\hline
\end{tabular}

At the end of the experiment, the formation of a value attitude to choreographic activity was carried out, as well as according to the methodology described above (a questionnaire was used, which highlighted 24 professional qualities that were important for the choreographer). The diagnostic data obtained at the beginning and end of the experiment are presented in Table 12 for comparison. The formation of a value attitude to choreographic activity at the end of the experiment was also performed using the above-described method (using a questionnaire containing 24 professionally significant qualities for the choreographer). Comparative data of the survey results at the beginning and end of the experiment is presented in Table 12.

Table 12. distribution of students by the level of formation of value attitude to choreographic activity at the beginning and end of the experiment

\begin{tabular}{|c|c|c|c|c|c|c|}
\hline \multirow{2}{*}{ Levels, groups } & \multicolumn{2}{|c|}{ Reproductive } & \multicolumn{2}{|c|}{ Adaptive } & \multicolumn{2}{|l|}{ Creative } \\
\hline & $\begin{array}{l}\text { Control } \\
\text { groups }\end{array}$ & $\begin{array}{l}\text { Experimenta } \\
\text { I groups }\end{array}$ & $\begin{array}{l}\text { Control } \\
\text { groups }\end{array}$ & $\begin{array}{l}\text { Experimen } \\
\text { tal groups }\end{array}$ & Control groups & $\begin{array}{l}\quad \text { Experim } \\
\text { ental } \\
\text { groups }\end{array}$ \\
\hline $\begin{array}{l}\text { At the beginning } \\
\text { of the experiment }\end{array}$ & $14(56 \%)$ & $13(52 \%)$ & $6(24 \%)$ & $8(32 \%)$ & $5(20 \%)$ & $4(16 \%)$ \\
\hline $\begin{array}{l}\text { At the end of } \\
\text { the experiment }\end{array}$ & 13 & - & $7(28 \%)$ & $13(52 \%)$ & $5(20 \%)$ & $12(48 \%)$ \\
\hline
\end{tabular}

At the end of the experiment, there was an increase in the share of students with whom adaptive and creative levels of professional mobility were formed in the component of the value attitude of students to choreographic activity, and there were no students left in the experimental group who demonstrated the reproductive level of the studied quality ( $52 \%$ and $48 \%$, respectively).

At the same time, it should be noted that there were no significant differences in the levels of formation of professional mobility in the control group, at the beginning and end of the experiment. Diagnostics of indicators on the socio-communicative component of the formation of the foundations of professional mobility was carried out by the same diagnostic methods (interview, interview, pedagogical control, method of self-assessment, method of expert assessment), which were used at the stage of determining the experiment for students of the control and experimental group. Comparative data are shown in Table 13.

Table 13. Comparative data of students with different indicators of professional mobility on the social and communicative component at the beginning and end of the pedagogical experiment.

\begin{tabular}{l|l|l|l}
\hline & Reproductive & Adaptive & Creative \\
\hline
\end{tabular}


Azizkhanova, D. K., Almetov, N. S., Turdaliyeva, S. Z., Aitzhanova, A. B., \& Musakhanova, G. M., (2021). Formation of professional mobility of future specialists in the process of choreographic education. Cypriot Journal of Educational Science. 16(4), 1680-1703. https://doi.org/10.18844/cjes.v16i4.6050

\begin{tabular}{|c|c|c|c|c|c|c|}
\hline Levels, groups & $\begin{array}{l}\text { Control } \\
\text { groups }\end{array}$ & $\begin{array}{l}\text { Experiment } \\
\text { al groups }\end{array}$ & $\begin{array}{l}\text { Control } \\
\text { groups }\end{array}$ & $\begin{array}{l}\text { Experime } \\
\text { ntal groups }\end{array}$ & $\begin{array}{l}\text { Control } \\
\text { groups }\end{array}$ & $\begin{array}{l}\quad \text { Experi } \\
\text { mental } \\
\text { groups }\end{array}$ \\
\hline $\begin{array}{l}\text { At the } \\
\text { beginning of the } \\
\text { experiment }\end{array}$ & $14(56 \%)$ & $13(52 \%)$ & $8(32 \%)$ & $9(36 \%)$ & $3(12 \%)$ & $3(12 \%)$ \\
\hline $\begin{array}{l}\text { At the end of } \\
\text { the experiment }\end{array}$ & $13(52 \%)$ & $2(8 \%)$ & $9(36 \%)$ & $13(52 \%)$ & $2(8 \%)$ & $10(40 \%)$ \\
\hline
\end{tabular}

The results of the experiment showed that in experimental groups there is a significant decrease in the number of students with the established level of reproductive professional mobility (from $52 \%$ at the beginning of the experiment to $8 \%$ at the end of the experiment) and, conversely, a significant increase in the number of students with the established level of professional mobility at the adaptive level (from $36 \%$ to $52 \%$ ). ). There is also a significant increase in the number of choreographers who have developed professional mobility at the creative level (from $12 \%$ to $40 \%$ ). At the same time, in the control groups, there are no special changes in the levels of the studied indicators of professional mobility of students (reproductive level - 56\% and 52\%, adaptive level - 32\% and 36\%, creative level $12 \%$ and $8 \%$ ).

Thus, the conducted experimental work confirms the effectiveness of the pedagogical conditions identified in the course of research on the formation and development of the foundations of professional mobility of students - future choreographers and the methodology developed on their basis.

\section{Discussion}

In the course of the research, an algorithm for the formation of professional mobility of students of the choreographic specialty has been developed, which includes the following organizational and methodological steps:

1. training of teachers teaching students of the specialty;

2. identification of the initial and final levels of important personal qualities and competencies of students that ensure professional mobility.

3. identification of the potential of the content of educational disciplines of the specialty for the formation of professional mobility of students and its enrichment, application of measures for the organization of the educational process;

4. introduction of a special course "professional mobility in Choreography" for students;

5. design methods, methodological approaches and tools for the formation of the foundations of professional mobility and their application in accordance with the specifics of choreographic education.

6. Planning and implementation of the formation of the foundations of effective mobility of students in the practice of educational production.

7. implementation of a set of extracurricular activities aimed at the formation of professional mobility qualities and competencies.

8. This algorithm is reflected in Figure 1, a methodological system developed in the course of research for the formation of the basics of professional mobility of the future choreographer. 
Azizkhanova, D. K., Almetov, N. S., Turdaliyeva, S. Z., Aitzhanova, A. B., \& Musakhanova, G. M., (2021). Formation of professional mobility of future specialists in the process of choreographic education. Cypriot Journal of Educational Science. 16(4), 1680-1703. https://doi.org/10.18844/cjes.v16i4.6050

Vertical mobility: career growth, social prestige growth: in the fields of Art, Culture, Education, Management, Science
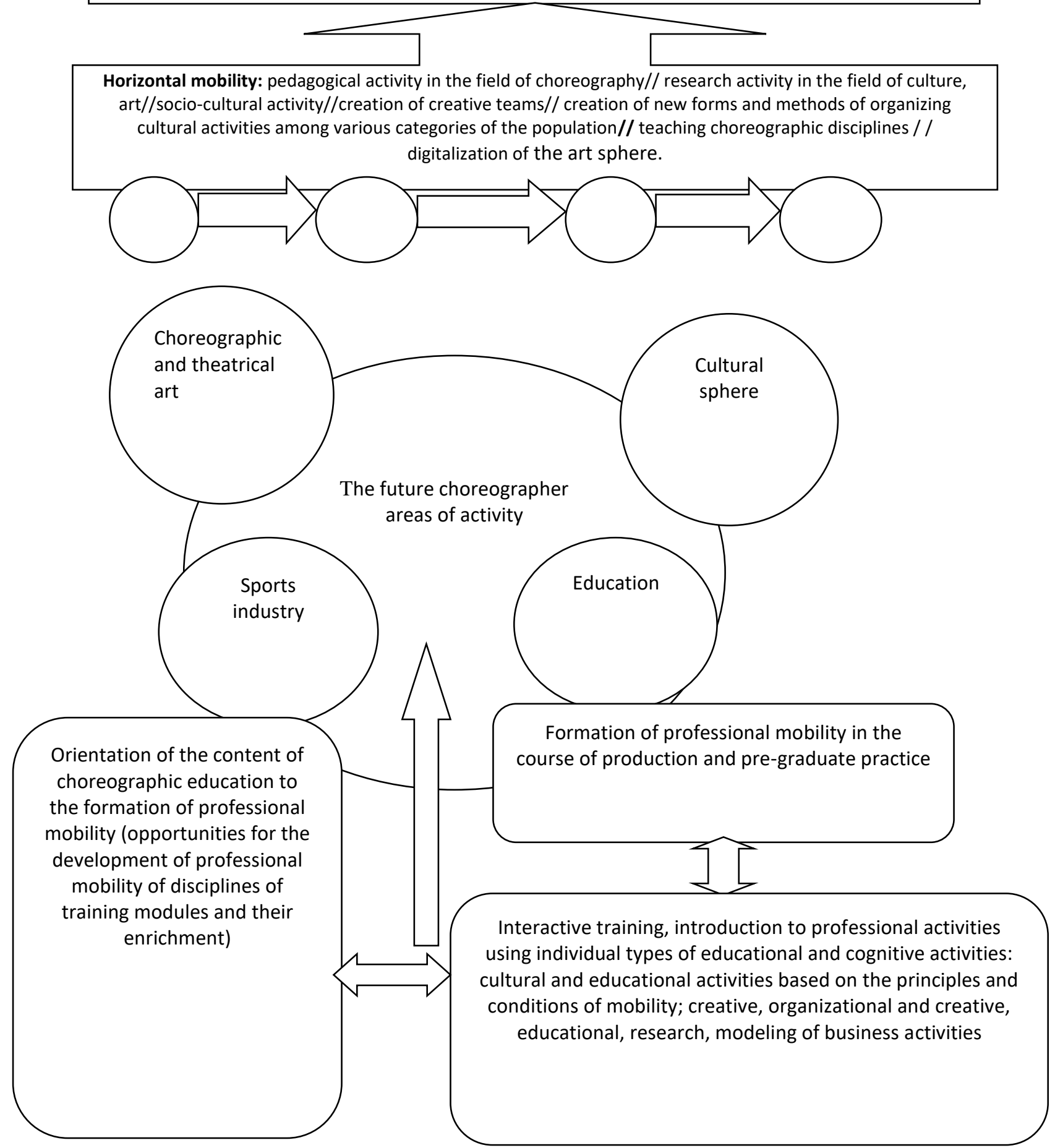

Figure 1. methodological system for the formation of professional mobility of the future choreographer. 
Of particular importance in the formation of the foundations of professional mobility of future choreographers is the updating of the motivational sphere of students, the development of their needs for self-education and self-development. In mastering the educational module "fundamentals of Social Sciences" of the modular educational program of The Bachelor's degree "choreography" (Dania, Hatziharistos, Koutsouba \& Tyrovola, 2011) within the framework of this component of the model for the formation of professional mobility, it is possible to develop specific methodological steps and present it in a single form of the system. For example, in the discipline" modern history of Kazakhstan "-" topic 30: Kazakhstan is a world-famous country", in the discipline" philosophy "- "topic 13". A comprehensive discussion of questions about the nature of mobility of the personality of a modern professional at lectures and practical classes on the topics" human problem in Philosophy"," Philosophy of global problems " gives good results. It is necessary to use interviews and discussions in their psychology, which contribute to the formation of a sense of professional mobility, motivational relationships, to make students understand that self-education, self-development are a special requirement for the future choreographer.

In the study of the discipline" self-knowledge", methods and methods of teaching are used in order to activate the reflexive activity of choreographers aimed at identifying individual (cognitive) cognitive styles, intellectual resources. Topic 16 in the program of the discipline" professional Kazakh (Russian) language". Within the framework of" education", topic 18" specialty "and topic 26" Science and innovative technologies", students are given tasks to schematically create tasks for priority tasks, a hierarchy of goals for the development of intellectual competencies, professional mobility. Students should present their ideas about the intellectual competencies, mobility and development of a choreographer and present them graphically. In the course of academic work in small groups, student choreographers clearly develop ideas for the development of professional mobility in future professional activities, and then submit them for collective discussion. Timely exchange of students ' opinions on mobility also provides for the development of their communication skills in the Kazakh and Russian languages (Dania, Hatziharistos, Koutsouba \& Tyrovola, 2011).

The program content of the course" professionally oriented foreign language "covers the topics:" professional activity in the life of a person","employment","resume","ways of professional development"," personal and professional growth of a student and a specialist"," competitiveness of a choreographer"," psychological portrait of a successful specialist"," outstanding representatives of the profession". The possibilities of supporting practical classes on these topics in order to form professional mobility are wide. For example, in practical classes on the topic" ways to improve skills", student choreographers perform exercises to design individual trajectories of continuing education based on the integration of formal, informal, and informational education of continuing education (Utemissova, Danna \& Nikolaevna, 2021; Ilhan, 2018).

In the lesson on the topic "competitiveness of a choreographer", students describe the expected changes in the near future in the field of choreographic art, or in the field of secondary choreographic education, and determine what the competition of a choreographer means in these conditions. Then a model of a competitive choreographer-specialist or teacher-choreographer is developed. These cognitive tasks were solved using methods of working with information from various sources, methods of induction, deduction, comparison, and generalization. Educational work in pairs or small groups can be continued in the form of debates, where students can exchange information reflecting polar views on the issue of professional mobility of a choreographer (Ilhan, 2018). 
In the lessons of the discipline" information and communication technologies", there is a high opportunity to form competencies that are most important for professional mobility of future choreographers. For example, in the course of studying the topic" Human-Computer Interaction", it is possible to clarify the interaction between human and digital tools on the example of choreographic and related areas of art.

Students are offered to prepare information and analytical material for a wide audience on the topic" Digital choreography" (Carraro \& Trinder, 2021). This material is recommended to be developed by students in the form of a three-round project:

- monopredmet (from the point of view of circalization of Human-Computer Interaction in the field of choreography);

-a project of professional mobility of a choreographer is developed in the context of digitalization by integrating interdisciplinary (knowledge acquired in the subject of information and communication technologies and disciplines of modules of special disciplines. These projects are mainly focused on the internal, intra-industry mobility of the choreographer);

- interdisciplinary projects (such projects are focused on the formation of flexible skills of students, are developed at the intersection of branches of knowledge. For example, it involves modeling the professional mobility of a choreographer-specialist, created at the intersection of the fields of Information Technology, choreography, musical art, and visual arts).

Business games are an effective methodological tool at all stages of the formation of professional mobility of future choreographers. As mentioned above, the professional mobility of the future choreographer is a complex integral characteristic of the choreographer, which is based on the cognitive support of knowledge in the field of choreographic art, dance performing skills and flexibility, emotional and artistic reactivity, social and creative adaptation, rehearsal-ring character variability and ensures the performance of multi-functional and multi-profile activities of the choreographer.

Professional knowledge and qualifications in the field of choreography are the foundation and foundation of professional mobility of the future specialist (Carraro \& Trinder, 2021). A student who has received a choreographic education, regardless of the direction in which he / she shows mobility after graduation, or even moves to another specialty in the field of choreography, or to another field of art, his / her professional mobility is formed on the basis of professional competencies in the choreographic field. Therefore, the formation of professional mobility of choreographers should be carried out in the process of teaching special academic disciplines. For example, in lectures and practical classes on the discipline" fundamentals of directing and acting", the formation of subject competencies in the specialty can solve the tasks of forming universal competencies and integrated professional mobility.In particular, topic 1 "General Provisions. In the lessons on" education of artistic taste", information is given about the importance of artistic taste, the mechanisms of its education, which are important for all branches of art, and in practical classes special exercises are used for the formation of artistic and aesthetic tastes of students. These exercises are performed on the material of recitsura and acting art. That is, through mastering the elements of directing and acting art, artistic and aesthetic tastes are brought up, which are important for the professional mobility of students.

When teaching choreographic disciplines, a special methodology for the development of imaginative artistic thinking is required, aimed at developing various ways of expressing students ' thoughts and experiences of perception. The objectives of this methodology are as follows:

- students should develop the ability to talk about works of art; 
-it is necessary to develop communication skills about art, the ability to think in the field of art. It is important that the conversation about art should be built taking into account the future profession of students and be the result of an organized admission process;

- it is important to teach students to use their impressions of observing reality in the story of works, in their own artistic experience;

- develop the ability to compare a choreographic work of art with similar phenomena in other areas of art, to feel their common connections with simplicity;

- teach students "graphic speech" in the process of perception, that is, to give the impression of work through drawing (quick sketches on memory). This method is directly related to the development of imaginative thinking, visual imaginative memory, and the mobility of perception responses.

The development of artistic and imaginative thinking of students of the specialty" choreography " has a positive impact on their assimilation of elements of professional thinking in other areas of art, such as visual arts. In the formation of professional mobility of future choreographers, it is important to strengthen interdisciplinary ties, organize a partnership strategy, team work of teachers of general professional and special disciplines. The method of modeling situations (situations) of professional mobility in the process of teaching choreographic disciplines gives good results. As mentioned above, the choreographer's mobility can be horizontal or vertical. Interviews with students show that the vast majority of choreographers-students, after graduating from the University, strive to work in their specialty, in the field of choreographic art. Therefore, in the process of teaching choreographic disciplines, we use the method of modeling pedagogical situations that form professional mobility.

The pedagogical situations that we simulate are primarily focused on the tasks of forming horizontal mobility of the choreographer. Student choreographers should be well aware that the formation of professional mobility does not necessarily mean a change in the social status of a choreographer, a transition to work in another field.

Practice has a special place and role in the formation of the foundations of professional mobility of the future choreographer. Pre-graduate practice is provided in the module" final attestation "of the modular educational program of the specialty" choreography". This module provides for the passage and protection of pre - graduate practice in the profile of specialization, which is held in various educational and cultural and leisure institutions: children's art schools, secondary specialized institutions, children's art houses, palaces of culture and Recreation, general education schools, colleges, kindergartens. The module includes two main areas: pedagogical and choreographer (production) activities".

When developing the methodology of student practice (practice), focused on the formation of the basics of professional mobility of the future choreographer, we base on the concept proposed by Zakrevskaya \& Makhailova, 2011). In the concept of pedagogical practice focused on the formation of professional mobility as a component and condition for the competitiveness of the future teacher, the authors put personal, activity, systematic, integrative, socio-cultural and competency-based aspects. The formation of professional mobility of Kazakhstani universities in the training of future choreographers based on existing forms of professional practice (continuous, pedagogical, pregraduate) requires a comprehensive approach.

The planned production practice at the 1,2 courses provides for the introduction of students to the specialty and the consolidation of theoretical and practical knowledge gained in the study of special 
disciplines. Students-choreographers get acquainted with the real practical activities of various art, cultural and educational organizations.

The Department of "choreography " develops a system of tasks for students-practitioners. These tasks are carried out in practice at production sites, the results of which are discussed in classes at the University. Tasks performed in practice are identified by the modules of special disciplines in terms of deadlines. For example, production practice in the 2 nd year is conducted in parallel with the subjects "introduction to the profession", "modern choreography I", "modern choreography II", "methods of teaching sports and balding dance I", "methods of teaching sports and balding Dance II", "methods of teaching sports and balding dance IV". Although this practice is called "passive" practice, it is essentially a psychological and pedagogical practice. The variability of tasks assigned to students is achieved. Individual tasks assigned are aimed at putting students in a state of transition from one type of activity to another type of activity (Keser \& Erdem, 2019).

Production practice, focused on the formation of the pedagogical activity of the future choreographer, provides for the following results:

According to the program, the student is a choreographer:

1. Fundamentals of planning the educational process;

2. modern methods and methods of teaching academic subjects.;

3. modern software products necessary for planning the educational process. ;

4. involve students in various educational and cognitive activities;

5.know the optimal combination of front-end, group and individual types of work with students.

According to the program, choreographers-students: participation in practice bases in accordance with the approved schedule; keeping a diary; performing the functions of a teacher-choreographer; preparing and conducting activities in the classroom; various types of assistance to the class teacher (preparation of didactic distribution materials, checking the execution of tasks through electronic diaries, etc.); inclusion in various types of assistance to the teacher-choreographer; performing individual, pair and Group Research tasks; completion of additional tasks (drawing up a"methodical collection chest", preparing presentations, summarizing the source base, portfolio ,etc.); the degree of participation in the preparation of a group Creative final report for the conference based on the results of practice at the University, etc. (Keser \& Erdem, 2019).

For example, you can give students individual tasks such as:

1. analyze the Performing and pedagogical activities of the teacher-choreographer, identify their special aspects and connections with each other.

2. make combinations on the dance material and make an Etude (by choice). Develop an algorithm for teaching students to it.

3. prepare a methodological development of a lesson on one topic dedicated to the Kazakh dance art.

4. identify students who are capable and talented in the field of choreographic art (using special research methods - observation, questionnaires, interviews, working with teachers and classroom teachers, studying school documents, analyzing products of students ' creativity, etc.).

5. Create a project to create a creative team (circle) of students capable of dance art.

6. conduct a small research work on the topic:" reflection of the Kazakh National Dance Art in modern dance art and its pedagogical significance". 
7. In the practice of Higher courses, trainee choreographers have the opportunity to join various types of activities: teaching choreographic disciplines, dance-performing, preparing stage productions, the activities of a choreographer-concertmaster, directing art and creative teams, research work in the field of methodological, cultural and art. Students perform tasks assigned by the department, collect practical materials necessary for coursework and theses.

In the orientation of the practice of student choreographers to professional mobility, the joint, coordinated work of the departments supervising the practice creates opportunities for achieving a multiplicity of tasks. For example, the creation of professional practice programs by the Department of" choreography "in coordination with the Departments of" Music Education"," General pedagogy"," psychology and defectology " ensures the variability of tasks. In this regard, the tasks given to students are variable, which presupposes the inclusion of future choreographers in various activities, not only in their dance-performing, ballet-master activities, but also in the multi-faceted activities of the future choreographer-pedagogical, concertmaster, directing, managerial, methodological, research activities, allowing them to penetrate deeper into real production processes (Hamdan, Isik \& Jallad, 2019).

Students-interns are given individual-differentiated tasks aimed at the formation of universal competencies and specific areas of the choreographer's activity (Dandashly, Barbar \& Antoun, 2019; Keser \& Erdem, 2019). Tasks aimed at the formation of universal competencies: "forms of organizing creative activities in art organizations", "methods of effective communication in a creative team", "planning continuous professional self-improvement of a choreographer", etc. For example, individual tasks that take into account the specifics of the professional activity of the future choreographer: "methods of teaching Kazakh dance", "organization of modern dance training", "organization of children's dance performance groups in extracurricular institutions", "work of the director in the preparation of choreographic stage productions", "musical accompaniment of choreographic stage productions", "training of national dance art in secondary special schools", "forms of Universal Dance Performance activities in Holiday Homes", "study of dance culture of different professions", "study of the history of dance art in the city", etc (Utemissova, Danna \& Nikolaevna, 2021; Kovacikova \& Luprichova, 2018).

From the point of view of professional mobility, special attention should be paid to determining the base of production and pre-graduate practices that students-choreographers pass. In particular, organizations of culture, art, and education, where industrial practice takes place, should be, first of all, institutions that successfully implement innovative programs.

In general, the production practice of students of The Bachelor's degree in the specialty "choreography" should be of a comprehensive nature, that is, it should include all types of professional activities of the choreographer.

\section{Conclusion}

Today, the stability of the personal and personal professional qualification potential of an employee formed in the course of many years of experience of professional activity is increasingly decreasing, on the contrary, dynamism, flexibility of professional skills and abilities come to the fore. So, today, a professional who is professionally ready to work successfully in rapidly changing conditions is more in demand. Mobility, i.e. a factor of professional mobility, rapid adaptation to new requirements and conditions, and the development of professional skills, is one of the factors of 
professional activity, professional formation and growth. Hence the legal condition for training future specialists who have mastered the basics of professional mobility in a higher educational institution. This is due to the fact that one of the most popular characteristics of a modern specialist is professional mobility, which characterizes the flexibility and variability of professional competencies, readiness for changes in the content of work, if necessary, to move from one professional level to another, and even to another profession.

Based on the developed theoretical provisions and data obtained during the experimental work, the following conclusions and recommendations were made:

- The conducted research proves the reality of the assumption of expediency of creating a unified system for the formation and development of the foundations of professional mobility of students future choreographers;

- the structure of professional mobility of the future choreographer reflects the process of movement of a specialist in the social and professional structure of society with or without changes in the social status and includes the following components: motivational, cognitive-activity, emotional-value and socio-communicative;

- the necessary conditions for an effective solution of the problem of forming the foundations of professional mobility of the future choreographer in a higher educational institution - design and implementation of a pedagogical system that provides for the most complete realization of the pedagogical potential of choreographic disciplines, the formation and development of a professionally mobile graduate of universities, the design of choreographic knowledge on the basis of a multifunctional methodological platform, its universalization, the creation of educational conditions for students to perform various professional functions within the framework of one lesson, the gradual expansion of types of professional training (profiles) of future choreographers.

- the methodology for forming the foundations of professional mobility of future choreographers simulates the professional mobility of a choreographer with a focus on the process of professional dynamics and is aimed at developing students ' competencies for successful professional and personal adaptation, newly emerging personality structures and behavioral reactions caused by them.

\section{References}

Autili, M., Di Salle, A., Gallo, F., Pompilio, C., \& Tivoli, M. (2019). A choreography-based and collaborative road mobility system for L'Aquila city. Future Internet, 11(6), 132. https://doi.org/10.3390/fi11060132

Berezhnaya, E. A. (2008). Development of the foundations of professional creativity of future choreographers in the process of studying the subjects of psychological and pedagogical cycle.PED.sciences'.- Rostov-ondon,-166 http://search.ebscohost.com/login.aspx?direct=true\&profile=ehost\&scope=site\&authtype=crawler\&jrnl $=18690459 \& A N=144307186 \& \mathrm{~h}=A z b \% 2 F 8 q r e E 30 \% 2 B M 4 M P h Q 8 h t R o l F a S 8182 F 2 N v N i x 7 k 866 w s i K 7 x n D X$ CVQL3yaje53c8RoEbGzFgt9TqXDihz4\%2BKA\%3D\%3D\&crl=c

Butova I. A. (2012). Formation of professional mobility of a musician-concertmaster in the process of studying at a music college / / Diss...candidate of pedagogical sciences.- Yekaterinburg,. - 217 p. https://www.frontiersin.org/articles/496185

Carraro, K., \& Trinder, R. (2021). Technology in formal and informal learning environments: Student perspectives. Global Journal of Foreign Language Teaching, 11(1), 39-50. https://doi.org/10.18844/giflt.v11i1.5219 
Azizkhanova, D. K., Almetov, N. S., Turdaliyeva, S. Z., Aitzhanova, A. B., \& Musakhanova, G. M., (2021). Formation of professional mobility of future specialists in the process of choreographic education. Cypriot Journal of Educational Science. 16(4), 1680-1703. https://doi.org/10.18844/cjes.v16i4.6050

Dandashly, N. A., Barbar, A., \& Antoun, M. (2019). The effects of using blogs and webquests in teaching education postgraduate courses. Global Journal of Information Technology: Emerging Technologies, 9(1), 12-19. https://doi.org/10.18844/giit.v9i1.4018

Dania A., Hatziharistos D., Koutsouba M., Tyrovola V. (2011). The content of integral competence of future music art and choreography teachers. Scientific Journal of National Pedagogical Dragomanov University. Series 14. Theory and methodology of arts education 29. Pp.68-75, https://doi.org/10.31392/NPU-nc.series14.2019.27.11

Dania, A., Hatziharistos, D., Koutsouba, M., \& Tyrovola, V. (2011). The use of technology in movement and dance education: Recent practices and future perspectives. Procedia-Social and Behavioral Sciences, 15, 33553361. https://doi.org/10.1016/i.sbspro.2011.04.299

Georgiadou, Z., Florou, V., \& Georgiadou, I. I. (2021). Contemporary condemnation of memory. Global Journal of Sociology: Current Issues, 11(1), 20-27. https://doi.org/10.18844/gis.v11i1.5449

Gromova, C. R., \& Saitova, L. R. (2016). Pedagogical Conditions of Formation of Professional Competence of Future Music Teachers on the Basis of an Interdisciplinary Approach. International Journal of Environmental and Science Education, 11(13), 6162-6177. https://eric.ed.gov/?id=EJ1115526

Hamdan, S., Isik, B., \& Jallad, S. T. (2019). Impact of creativity in nursing education. New Trends and Issues Proceedings on Advances in Pure and Applied Sciences, (11), 39-45. https://doi.org/10.18844/gipaas.v0i11.4312

Ilhan, A. C. (2018). Artists participating in the 15th Istanbul biennial in Turkey. New Trends and Issues Proceedings on Humanities and Social Sciences, 5(6), 106-113. https://doi.org/10.18844/prosoc.v5i6.3846

Keser, S. C., \& Erdem, P. (2019). The Effectiveness of Plastic Arts Education Weighted Creative Drama in The Education of Gifted / Talented Children. Contemporary Educational Research Journal, 9(1), 32-37. https://doi.org/10.18844/ceri.v9i1.3856

Khalid F. (2019). The Choreography of Talent Development in Higher Education Higher Education Studies. 9(1). 40-52. URL: https://doi.org/10.5539/hes.v9n1p40

Kovacikova, E., \& Luprichova, J. (2018). A good CLIL practice among European educational institutions. International Journal of Learning and Teaching, 10(1), 50-60. https://doi.org/10.18844/ijlt.v10i1.3145

Leijen, Ä., Wildschut, E. M. M., Admiraal, W., \& Simons, P. R. J. (2006, July). Pedagogical context of practical dance classes in higher education: A case of Dutch choreography and technique teachers. In Colouring senses dance and the child international conference 10th edition (pp. 99-108). Dance and the Child International. https://www.researchgate.net/publication/27697779

Limanskaya, O.V., Kriventsova, I.V., Leonid, V. P., Yefimova, O.V., Marina Jagiello, (2020). The influence of professional training disciplines on the physical fitness level of the folk dance department students Pedagogy of physical culture and sports, 24(5). 248-254. https://doi.org/10.15561/26649837.2020.0505

Lusdoc, C. S., \& Namoco, R. A. (2019). Selecting an SPA (special program in the arts) major for high school students using AHP combined with interest inventory. International Journal of Innovative Research in Education, 6(1), 1-11. https://doi.org/10.18844/ijire.v9i1.4118

Mead, D. (2020). ReOrienting Taiwan's Modern Dance: The New Generation of Taiwanese Choreographers. In Identity and Diversity (pp. 175-192). Routledge India. https://www.taylorfrancis.com/chapters/edit/10.4324/9780367818425-11/reorienting-taiwan-moderndance-new-generation-taiwanese-choreographers-david-mead 
Mishchenko, V. A., Belova, L.A., Frolova, E.V., V. Torkunova, Aleksandr V. Dudov, Radik M. Galiyev, Mikhail P. Palyanov, J., Tenyunina, I. A. (2016). Management Factors and Conditions of Higher Education Students Professional Mobility Formation. International Review of Management and Marketing, 6(1), 70-74. https://www.proquest.com/openview/35ab71984a7e82b645efc42811a8b422/1?pqorigsite $=$ gscholar $\& \mathrm{cbl}=816339$

Pavlenko, M. A. R. I. N. A. (2017). The problem of developing professional mobility of teachers in the works of foreign scholars. https://doi.org/10.1515/rpp-2017-0061

Tezer, M. (2020). Academic procrastination behaviours and problematic internet usage of high school students during the COVID-19 pandemic period. International Journal of Special Education and Information Technologies, 6(1), 01-17. https://doi.org/10.18844/jeset.v6i1.5490

Utemissova, G. U., Danna, S. ., \& Nikolaevna, V. N. (2021). Cyberbullying during the COVID-19 pandemic. Global Journal of Guidance and Counseling in Schools: Current Perspectives, 11(2), 77-87. https://doi.org/10.18844/gigc.v11i2.5471

von der Lippe, P. (2010). Price indices on the basis of unit values: Unit value indices as proxies for price indices (No. 185). Diskussionsbeitrag. http://hdl.handle.net/10419/43588

Yusov, B.P. (2002). Fine arts and children's fine arts. Essays on the history, theory and psychology of artistic education of children. Magnitogorsk: MAU.

Zakrevskaya, N.G., Makhailova, E.Ya. (2018). Professional mobility as a factor of professional improvement of specialists in the field of physical culture and sports / / Scientific notes of the University named after P. $\begin{array}{llll}\text { F. } & 4(158), & \text { Pp. } & \text { 98-101. }\end{array}$ https://www.tandfonline.com/doi/abs/10.1080/0142159X.2021.1931082

Zeer, E.F. ( 2014). Socio-psychological mobility of students as a factor of preparation for a dynamic professional future, Education and science, 8(1), 534-540. http://www.asee.org/file server/papers/attachment/file/0003/4633/Khramova-Khramov-TamilinaIvanov.pdf

Zharkov, A.D. (2007) Theory and technology of cultural and leisure activities / AD Zharkov. - M .: MGUKI, 2007 480 p. [in Russian] 